\title{
Management of constipation in preventing urinary tract infections in children: a concise review
}

\author{
Marco Zaffanello $\odot$, Claudia Banzato $\odot$, Giorgio Piacentini $\odot$
}

Department of Surgical Sciences, Dentistry, Gynecology and Pediatrics, Section of Pediatrics, University of Verona, Verona, Italy

DOI: 10.18621 /eurj.412280

\begin{abstract}
Objectives: Constipation is a common problem in children. Chronic functional constipation (CFC) has been a claimed conditions that may increase the risk for urinary tract infections (UTIs). Dysfunctional voiding (DV) and lower urinary tract dysfunctions (LUTD) with chronic constipation are referred to dysfunctional elimination syndromes (DES). The aim of the present review is to look at the management of constipation in children with CFC or DES in reducing the risk of recurrent UTIs.

Methods: We performed a literature search on electronic databases (Pubmed and Scopus) for relevant clinical trials investigating the results of one or more treatments for children's constipation in the term of UTIs recurrence.

Results: The search strategy identified 20 valuable clinical trials. The studies are not homogenous but showed an improvement in UTIs occurrences in children managed for bowel dysfunction.

Conclusion: In conclusion, children referred to a pediatric nephrologist for UTIs should include an inquiry bowel habits and those with a positive assessment for bowel dysfunction needs the collaboration with a pediatric gastroenterologist with a multidisciplinary approach.
\end{abstract}

Keywords: Children, constipation, dysfunctional elimination syndromes, dysfunctional voiding, urinary tract infection

Received: April 3, 2018; Accepted: June 14, 2018; Published Online: September 16, 2018

$\mathrm{U}$ rinary tract infections (UTIs) are frequent in children. By seven years of age, $8 \%$ of girls and $2 \%$ of boys will have had at least one episode of UTI [1]. Prospective studies using 99mTc-labelled dimercaptosuccinic acid (DMSA) scintigraphy have shown that, after a febrile UTI, $30-40 \%$ of children will have renal scarring [2]. Follow-up data has established that long-term complications of UTIs with renal scarring include hypertension, proteinuria, pregnancy-related complications and even end-stage kidney failure [3]. Many predisposing factors to UTIs recurrence (vesicoureteral reflux [VUR], bladder and bowel dysfunction [BBD], and genetic factors) have described in childhood $[4,5]$. Both BBD and VUR are at high risk of developing recurrent UTIs than children with isolated VUR or children with isolated BBD [6]. There is still controversy about the role of chronic functional constipation $(\mathrm{CFC})$ in predisposing children to UTIs [7].

Constipation is a common problem in children with a prevalence from $0.7 \%$ to $29.6 \%$ [8]. According to the Paris Consensus on Childhood Constipation Terminology (PACCT) Group, CFC as having at least two symptoms during the last eight weeks that include

Address for correspondence: Marco Zaffanello, MD., University of Verona, Department of Surgical Sciences, Dentistry, Gynecology and Pediatrics, Section of Pediatrics, Verona, Italy 
defecation frequency of less than three times, a fecal incontinence, frequency more than once, passage of large stools that clog the toilet, a palpable abdominal or rectal fecal mass, stool withholding and painful defecation [9]. CFC is chronic constipation without evidence of pathological conditions [10] and, at present, the most accepted definitions for CFC are the Rome III criteria [11]. In particular, sensation of anorectal blockage, straining during defecation and infrequent bowel movements are of great accuracy for the diagnosis of CFC [12]. Constipation may play a role in function and dysfunction of the urinary tract [13].

Dysfunctional voiding (DV), that refers to an intermittent and/or fluctuating uroflow rate due to involuntary intermittent contractions of the striated muscle of the external urethral sphincter or pelvic floor during voiding in normal individuals [14], and lower urinary tract dysfunctions (LUTD), that refers to patients with problems of bladder function [14], as dysfunctional elimination syndromes (DES) [15] with CFC [16]. DES and CFC increased the risk of UTIs in children [15, 17]. In agreement, it has observed recurrent UTIs in $25 \%$ of boys and $66 \%$ of girls among 180 patients with CFC [19], and in $62 \%$ of girls among 80 patients with DES [18].

Children with UTIs have more symptoms of constipation than without [20]. Wan et al. [21] suggested that up to $90 \%$ of children with UTI could have dysfunctional voiding or constipation habits.

Although the degree of fecal loading, as seen on a plain abdominal radiograph, is not synonymous of constipation, there is a significant association between the degree of fecal loading and UTIs [22]. Decreased bladder filling, impression of the bladder wall provoking overactivity, and pelvic floor discoordination caused by withdrawal manoeuvres as a response to painful defecation can have an important clinical meaning [23]. Another hypothesis is that constipation can figure bacterial stasis with huge proliferation and translocation of the same bacteria into genitourinary apparatus. In fact, it has reported a correlation between intestinal bacterial stasis, methanogenic intestinal flora and UTIs [24].

The general approach to the child with functional constipation comprises dietary interventions (high fibre diet, hydration changes), behavioural change, regular toilet habits and laxatives to assure that bowel movements occur at normal intervals with good evacuation [11].

The aim of the present look at to check if management of constipation in children with CFC or DES reduce the risk of UTIs recurrence.

\section{METHODS}

We performed a systematic literature search on electronic databases (Pubmed and Scopus) for relevant clinical trials published from January 1985 to June 2018 , investigating the results of one or more treatments for children's constipation in the term of the resolution or amelioration of UTIs recurrence.

To find relevant articles in these electronic databases, we used the keywords constipation OR dysfunctional elimination syndrome OR dysfunctional voiding AND urinary tract infection AND children.

Studies were qualified for inclusion if they were clinical trials (excluding observational studies, letters, case reports, conference abstracts, studies on animals and comments), searching for the role of one or more treatments for constipation in the term of the resolution or amelioration of UTIs recurrence.

First, we screened the list of titles and abstracts (total number identifies: 321); then we selected clinical trials and the articles of interest in their entirety. The strategy identified 20 clinical trials. We extracted the first author and year of publication, the number of cases, characteristics of constipation and treatment, and time of follow-up. We extracted information on the prevalence of constipation and UTI before and after the treatment.

\section{RESULTS}

\section{Clinical trials}

Twenty clinical trials (Table 1) involving patients with CFC or DES reported different treatment regimens for constipation (laxatives, enemas, highfibre diet, biofeedback therapy, pelvic floor muscle exercises, sacral neuromodulation, regular voiding, pharmacotherapy etc.) [23, 25-43].

Studies that showed a significant reduction of UTIs related to DV [26-28, 40] or DES [29, 30, 32] or LUTD [42]. Other studies did not report if the results 
Table 1. Characteristics and analysis of the included clinical trials

\begin{tabular}{|c|c|c|c|c|c|c|c|}
\hline Clinical trials & n. $(\mathbf{M} / \mathbf{F})$ & $\begin{array}{l}\text { Mean age } \\
\text { (range) }\end{array}$ & Main pathology & Treatment & $\begin{array}{l}\text { Follow- } \\
\text { up }\end{array}$ & $\begin{array}{c}\text { n. of patients } \\
\text { with } \\
\text { constipation } \\
\text { before/after } \\
\end{array}$ & $\begin{array}{c}\text { n. of patients } \\
\text { with UTI } \\
\text { before/after }\end{array}$ \\
\hline $\begin{array}{c}\text { Chrzan } 2008 \\
{[23]}\end{array}$ & $50(6 / 44)$ & $\begin{array}{c}9.6 \\
(6.5-12) \mathrm{yrs}\end{array}$ & $\begin{array}{l}\text { CFC, recurrent } \\
\text { UTIs }\end{array}$ & Colonic washout enemas & $6 \mathrm{mos}$ & $\begin{array}{c}50 / 33 \\
p=\text { n.a. }\end{array}$ & $\begin{array}{c}50 / 20 \\
p=\text { n.a. }\end{array}$ \\
\hline Kibar 2007 [25] & $78(8 / 70)$ & $\begin{array}{l}7.20 \pm 2.04 \\
(5-14) \mathrm{yrs}\end{array}$ & $\begin{array}{l}\mathrm{DV} \text {, vescico- } \\
\text { ureteral reflux }\end{array}$ & $\begin{array}{l}\text { Biofeedback, timed } \\
\text { voiding }\end{array}$ & $6 \operatorname{mos}$ & $\begin{array}{c}9 / 2 \\
p=\text { n.a. }\end{array}$ & $\begin{array}{c}41 / 8 \\
p=\text { n.a }\end{array}$ \\
\hline Vesna $2010[26]$ & $\begin{array}{l}86(35 / 51) \\
\text { Group A } 43 \\
\quad(15 / 28) \\
\text { Group B } 32 \\
\quad(9 / 23)\end{array}$ & $\begin{array}{l}7.1 \pm 2.5 \\
(3-13) \mathrm{yrs}\end{array}$ & DV & $\begin{array}{l}\text { Group A) Standard } \\
\text { urotherapy, pelvic floor } \\
\text { exercises } \\
\text { Group B) conservative } \\
\text { treatment } \\
\text { Laxatives; antibiotic } \\
\text { prophylaxis if UTIs } \\
\text { recurred in both groups }\end{array}$ & $1 \mathrm{yr}$ & $\begin{array}{c}\text { Group A } \\
15 / 0 \\
p<0.001 \\
\text { Group B } \\
10 / 4 \\
p<0.05\end{array}$ & $\begin{array}{c}\text { Group A } \\
19 / 6 \\
p<0.0001 \\
\text { Group B } \\
15 / 9 \\
p<0.05\end{array}$ \\
\hline Vesna 2011 [27] & $\begin{array}{l}86(35 / 51) \\
\text { Group A } 43 \\
\quad(15 / 28) \\
\text { Group B } 32 \\
\quad(9 / 23)\end{array}$ & $\begin{array}{c}\text { Group A } \\
7.5 \pm 2.5 \text { yrs } \\
\text { Group B } \\
6.7 \pm 2.5 \text { yrs }\end{array}$ & DV & $\begin{array}{l}\text { Group A) diaphragmatic } \\
\text { breathing, pelvic floor } \\
\text { muscles retraining plus } \\
\text { group B treatment, } \\
\text { Group B) regular voiding, } \\
\text { hydration, posture, } \\
\text { laxatives; antibiotic } \\
\text { prophylaxis if UTIs } \\
\text { recurred }\end{array}$ & $1 \mathrm{yr}$ & $\begin{array}{c}\text { Group A } \\
15 / 0 \\
p<0.0001 \\
\text { Group B } \\
10 / 4 \\
p<0.05\end{array}$ & $\begin{array}{c}\text { Group A } \\
19 / 6 \\
p<0.001 \\
\text { Group B } \\
15 / 9 \\
p<0.05\end{array}$ \\
\hline $\begin{array}{c}\text { Zivkovic } 2012 \\
{[28]}\end{array}$ & $43(15 / 28)$ & $\begin{array}{l}7.5 \pm 2.5 \\
(5-13) \mathrm{yrs}\end{array}$ & DV & $\begin{array}{l}\text { Pharmacotherapy (11 } \\
\text { anticholinergics, } 11 \\
\text { desmopressin, } 15 \\
\text { antibiotic prophylaxis); } \\
\text { constipation treatment } \\
\text { (education and laxatives); } \\
\text { diaphragmatic breathing } \\
\text { exercises; pelvic floor } \\
\text { muscle exercises }\end{array}$ & $1 \mathrm{yr}$ & $\begin{array}{c}15 / 0 \\
p<0.0001\end{array}$ & $\begin{array}{c}19 / 6 \\
p<0.0001\end{array}$ \\
\hline $\begin{array}{c}\text { Kajbafzadeh } \\
2011[29]\end{array}$ & $\begin{array}{l}80(18 / 62) \\
\text { Group A } 40 \\
(8 / 32) \\
\text { Group B } 40 \\
\quad(10 / 30)\end{array}$ & $\begin{array}{c}\text { Group A } \\
8.5 \pm 2.7 \text { yrs } \\
\text { Group B } \\
9 \pm 2.3 \text { yrs }\end{array}$ & DES & $\begin{array}{c}\text { Group A) animated } \\
\text { biofeedback therapy and } \\
\text { behavioral modification } \\
\text { Group B) conservative } \\
\text { therapy (only behavioral } \\
\text { modification) }\end{array}$ & $\begin{array}{c}6 \text { and } \\
12 \text { mos }\end{array}$ & $\begin{array}{c}\text { Group A } \\
25 / 8 / 8 \\
\text { Group B } \\
20 / 12 / 12 \\
6 \text { mos: } \\
p=0.01 \\
12 \text { mos: } \\
p=0.009\end{array}$ & $\begin{array}{c}\text { Group A } \\
14 / 2 / 4 \\
\text { Group B } \\
22 / 5 / 10 \\
6 \text { mos: } \\
p=0.02 \\
12 \text { mos: } \\
p=0.3\end{array}$ \\
\hline $\begin{array}{c}\text { Humphreys } \\
2006[30]\end{array}$ & $23(8 / 15)$ & $(6-15) \mathrm{yrs}$ & Severe DES & $\begin{array}{l}\text { Sacral neuromodulation, } \\
\text { medical therapy }\end{array}$ & $\begin{array}{l}(4-37 \\
\text { mos }) \\
\text { mean } \\
13.3 \\
\text { mos }\end{array}$ & $\begin{array}{c}15 / 3 \\
p=0.001\end{array}$ & $\begin{array}{c}18 / 6 \\
p<0.0001\end{array}$ \\
\hline $\begin{array}{c}\text { De Paepe } 2000 \\
{[31]}\end{array}$ & $20(2 / 18)$ & $\begin{array}{l}\text { M } 4.5 \text { yrs } \\
\text { F } 4.44 \text { yrs }\end{array}$ & DV & $\begin{array}{l}\text { Training program, } \\
\text { biofeedback, antibiotic } \\
\text { prophylaxis if UTIs } \\
\text { recurred, drugs to relieve } \\
\text { the impaction of } \\
\text { encopresis }\end{array}$ & $\begin{array}{l}6-12 \\
\text { mos }\end{array}$ & $\begin{array}{c}8 / 3 \\
p=\text { n.a }\end{array}$ & $\begin{array}{c}8 / 0 \\
p=\text { n.a. }\end{array}$ \\
\hline
\end{tabular}


Table 1 continued. Characteristics and analysis of the included clinical trials

\begin{tabular}{|c|c|c|c|c|c|c|c|}
\hline Clinical trials & n. $(\mathbf{M} / \mathbf{F})$ & $\begin{array}{l}\text { Mean age } \\
\text { (range) }\end{array}$ & Main pathology & Treatment & $\begin{array}{l}\text { Follow- } \\
\text { up }\end{array}$ & $\begin{array}{l}\text { n. of patients } \\
\text { with } \\
\text { constipation } \\
\text { before/after }\end{array}$ & $\begin{array}{l}\text { n. of patients } \\
\text { with UTI } \\
\text { before/after }\end{array}$ \\
\hline $\begin{array}{l}\text { Vasconcelos } \\
2006[32]\end{array}$ & $\begin{array}{l}56(18 / 62) \\
\text { Group } 126 \\
\quad(9 / 17) \\
\text { Group 2 } 30 \\
(10 / 20)\end{array}$ & $\begin{array}{c}\text { Group } 1 \\
10.8 \pm 1.9 \text { yrs } \\
\text { Group } 2 \\
10.3 \pm 2.6 \text { yrs }\end{array}$ & DES & $\begin{array}{c}\text { Group 1) } 24 \text { training } \\
\text { sessions over a 3-month } \\
\text { period } \\
\text { Group 2) } 16 \text { training } \\
\text { sessions over 2-month } \\
\text { period }\end{array}$ & $12 \mathrm{mos}$ & $\begin{array}{c}\text { Group } 1 \\
11 / 7 \\
p=\mathrm{n} . \mathrm{s} \\
\text { Group } 2 \\
11 / 9 \\
p=\mathrm{n} . \mathrm{s}\end{array}$ & $\begin{array}{c}\text { Group } 1 \\
8 / 1 \\
p=0.023 \\
\text { Group } 2 \\
13 / 3 \\
p=0.004\end{array}$ \\
\hline $\begin{array}{c}\text { Yagci } \\
2005[33]\end{array}$ & $168(16 / 152)$ & $\begin{array}{c}7.44 \pm 2.24 \\
(5-14) \mathrm{yrs}\end{array}$ & DV & $\begin{array}{c}\text { Biofeedback, timed } \\
\text { voiding, high-fiber diets, } \\
\text { laxatives }\end{array}$ & $\begin{array}{l}6 \text { mos } \\
\text { and } 2 \\
\text { yrs }\end{array}$ & $\begin{array}{l}26 / 7 / 9 \\
p=0.5\end{array}$ & $\begin{array}{l}102 / 17 / 13 \\
p=0.125\end{array}$ \\
\hline $\begin{array}{c}\text { McKenna } \\
1999[34]\end{array}$ & $41(8 / 33)$ & $\begin{array}{c}7.2 \\
(5-11) \mathrm{yrs}\end{array}$ & DV & $\begin{array}{l}\text { Pelvic floor muscle } \\
\text { retraining using interactive } \\
\text { computer games, timed } \\
\text { voiding, high-fiber diet }\end{array}$ & $\begin{array}{c}(3-15 \\
\text { mos }) \\
\text { mean } 7 \\
\text { mos }\end{array}$ & $\begin{array}{c}6 \\
\text { Improved: } 66 \% \\
\text { Cured: } \\
34 \% \\
p=\text { n.a. }\end{array}$ & $\begin{array}{c}22 / 3 \\
p=\text { n.a. }\end{array}$ \\
\hline $\begin{array}{c}\text { Barroso } \\
2006[35]\end{array}$ & 36 (n.a.) & $\begin{array}{c}7 \\
(3-14) \mathrm{yrs}\end{array}$ & LUTD & $\begin{array}{l}\text { Electrical stimulation } \\
\text { and/or biofeedback } \\
\text { training, behavioral } \\
\text { training, antibiotic } \\
\text { prophylaxis }\end{array}$ & $\begin{array}{c}(4-24 \\
\text { mos }) \\
\text { mean } \\
13.8 \\
\text { mos }\end{array}$ & $\begin{array}{c}12 / 3 \\
p=\text { n.a. }\end{array}$ & $\begin{array}{c}25 / 4 \\
p=\text { n.a. }\end{array}$ \\
\hline $\begin{array}{l}\text { Petronijevic } \\
2007[26]\end{array}$ & 9 (girls) & $\begin{array}{c}6.1 \\
(3-11) \mathrm{yrs}\end{array}$ & DV & $\begin{array}{l}\text { Botulin Toxin type A, } \\
\text { standard urotherapy, } \\
\text { education, regular toilet } \\
\text { visits, dietary and } \\
\text { hydration changes, } \\
\text { laxatives }\end{array}$ & $6 \mathrm{mos}$ & $\begin{array}{c}2 / 1 \\
p=\text { n.a. }\end{array}$ & $\begin{array}{c}8 / 2 \\
p=\text { n.a. }\end{array}$ \\
\hline $\begin{array}{c}\text { O'Regan } 1985 \\
\text { [37] }\end{array}$ & 47 (girls) & $8.2 \pm 2.53 \mathrm{yrs}$ & $\begin{array}{l}\text { Recurrent UTIs, } \\
\text { constipation }\end{array}$ & Enema regimen & $\begin{array}{l}12 \pm 2 \\
\text { mos }\end{array}$ & $\begin{array}{c}47 / 2 \\
\text { Encopresis } 21 / 1 \\
p=\text { n.a. }\end{array}$ & $\begin{array}{c}47 / 3 \\
p=\text { n.a. }\end{array}$ \\
\hline $\begin{array}{c}\text { Loening-Baucke } \\
1997[38]\end{array}$ & $234(176 / 58)$ & $\begin{array}{c}9 \pm 3 \\
(5-18) \text { yrs }\end{array}$ & CFC, encopresis & $\begin{array}{l}\text { Disimpaction (hypertonic } \\
\text { phosphate enemas OR } \\
\text { hyperosmolar milk-of- } \\
\text { molasses enemas), fiber- } \\
\text { rich foods, laxatives, } \\
\text { education, prophylaxis if } \\
\text { UTIs recurred }\end{array}$ & $\begin{array}{l}12 \\
\text { months } \\
\text { (mean, } \\
15 \\
\text { months } \\
\text { ) }\end{array}$ & $\begin{array}{l}234 / 112 \\
p=\text { n.a. }\end{array}$ & $\begin{array}{c}25 / 0 \\
p=\text { n.a. }\end{array}$ \\
\hline $\begin{array}{c}\text { Loening-Baucke } \\
1989[39]\end{array}$ & $97(69 / 28)$ & $\begin{array}{c}9.0 \\
(5-14.5) \mathrm{yrs}\end{array}$ & $\begin{array}{l}\text { CFC, overflow } \\
\text { incontinence }\end{array}$ & $\begin{array}{l}\text { Laxatives, high fiber diet, } \\
\text { bowel training }\end{array}$ & $12 \mathrm{mos}$ & $\begin{array}{c}97 / 43 \\
(\mathrm{~F}>\mathrm{M})\end{array}$ & $\begin{array}{l}\text { n.a. (UTI in } \\
\text { recovered } 3 / 43, \\
\text { UTI in non- } \\
\text { recovered } 11 / 54 ; \\
\quad p=\text { n.s. }\end{array}$ \\
\hline $\begin{array}{c}\text { Khen-Dunlop } \\
2006[41]\end{array}$ & $60(12 / 48)$ & $\begin{array}{c}8 \\
(5-14) \mathrm{yrs}\end{array}$ & DV & $\begin{array}{l}\text { Pelvic floor training, } \\
\text { regular voiding }\end{array}$ & $21 \mathrm{mos}$ & $25 /$ n.a. & $37 / 6$ \\
\hline $\begin{array}{c}\text { Amira } \\
2013[42]\end{array}$ & 72 (girls) & $\begin{array}{c}8 \\
(7-10) \mathrm{yrs}\end{array}$ & LUTD & $\begin{array}{l}\text { Standard and computer } \\
\text { game assisted pelvic floor } \\
\text { muscle retraining }\end{array}$ & $\begin{array}{c}(6-17 \\
\text { weeks) } \\
\text { mean } \\
11 \\
\text { weeks }\end{array}$ & $\begin{array}{c}36 / \text { n.a. } \\
p<0.002\end{array}$ & $\begin{array}{c}\text { 70/n.a. } \\
p<0.001\end{array}$ \\
\hline $\begin{array}{c}\text { Tugtepe } 2015 \\
{[40]}\end{array}$ & 45 (38 female) & $8.5 \pm 2.2$ years & $\begin{array}{l}\text { DV, refractory } \\
\text { overactive } \\
\text { bladder }\end{array}$ & Biofeedback therapy & $\begin{array}{c}3 \\
\text { months }\end{array}$ & $\begin{array}{c}8 / 1 \\
p<0.05\end{array}$ & $\begin{array}{c}20 / 4 \\
p<0.001\end{array}$ \\
\hline
\end{tabular}


Table 1 continued. Characteristics and analysis of the included clinical trials

\begin{tabular}{|c|c|c|c|c|c|c|c|}
\hline Clinical trials & n. $(\mathbf{M} / \mathbf{F})$ & $\begin{array}{c}\text { Mean age } \\
\text { (range) }\end{array}$ & Main pathology & Treatment & $\begin{array}{c}\text { Follow- } \\
\text { up }\end{array}$ & $\begin{array}{c}\text { n. of patients } \\
\text { with } \\
\text { constipation } \\
\text { before/after }\end{array}$ & $\begin{array}{l}\text { n. of patients } \\
\text { with UTI } \\
\text { before/after }\end{array}$ \\
\hline $\begin{array}{c}\text { Sarvari } 2017 \\
{[43]}\end{array}$ & $\begin{array}{c}105 \text { CFC }(23.8 \% \\
\text { males }) \\
104 \text { controls } \\
(26 \% \text { males })\end{array}$ & $\begin{array}{c}\text { CFC } \\
4.38 \pm 2.38 \text { yrs } \\
\text { Controls } 4.43 \pm \\
2.44 \text { yrs }\end{array}$ & $\mathrm{CFC}$ & $\begin{array}{l}\text { Lifestyle changes, child's } \\
\text { family } \\
\text { life style modification, } \\
\text { increased physical } \\
\text { activity, and } \\
\text { pharmacotherapy }\end{array}$ & $\begin{array}{c}3 \\
\text { months }\end{array}$ & $\begin{array}{c}\text { CFC } \\
105 / 68\end{array}$ & $-3.8 \%$ \\
\hline
\end{tabular}

$\mathrm{CFC}=$ chronic functional constipation, $\mathrm{DES}=$ dysfunctional elimination syndrome, $\mathrm{DV}=$ dysfunctional voiding (urinary incontinence, hesitancy, straining, intermittency, weak stream), LUTD = lower urinary tract dysfunctions, n.a. = not available, n.s. $=$ not significant

were different [23, 25, 31, 34-38, 43].

Few studies applied a randomization [26, 27, 29, 32]. In two studies by Vesna et al. [26, 27] divided the patients into two groups to compare different treatment regimens for DV; both groups had significant positive results in terms of amelioration of UTI recurrence and constipation. In another study, Kajbafzadeh et al. [29] randomized patients into 2 groups (biofeedback and conservative treatment) reporting a significant improvement of both constipation and UTI recurrence. Vasconcelos et al. [32], who compared two different treatments for DES, reported in both groups a significant improvement only in UTIs recurrences, because the prevalence of constipation had not decreased at follow-up compared to baseline.

Published studies involved a variable number of patients, from small cohorts of patients to a wide number (mean 71.4 patients, range 9-234), and often were only partial $[41,42]$.

A study of Loening-Baucke [38] is the one with the largest number of patients. The author observed that in 234 children with known CFC and encopresis which treatment of constipation could prevent UTIs in $10 \%$ of patients with recurrent UTIs. In a study by the same author [39], treatment of constipation resulted in amelioration of the $\mathrm{CFC}$ but reported no results in terms of UTI incidence. Khen-Dunlop et al. [41] reported the outcome only to resolve UTI recurrences and not for constipation. A recent study involving 209 children, CFC treatment did not show a significant (not stated) amelioration of UTIs recurrences [43]. In particular, this case-control study (105 CFC children versus 104 controls) showed that the prevalence of UTI in case and control groups was $13.3 \%$ and $6.7 \%$ $(p=0.17)$, showing a large link between constipation and UTIs, but the prevalence of UTIs in case group decreased only to $3.8 \%$ after treatment of constipation [43].

A bias in the clinical trials $[26-28,31,35,38]$ was the association between antibiotic prophylaxis, used if UTIs recurred, and constipation treatment.

\section{DISCUSSION}

UTIs recurrence prevention in children is again a challenge question whether antimicrobial prophylaxis is still a matter of debate. It has conducted investigtions to find optimal approaches to the assessment and management of UTIs and later interventions [44, 45].

Studies suggested a link between constipation and UTI recurrences in children. Guidelines for children with UTIs considered for investigate and managing of the bowel dysfunctions. The studies conducted so far reported a large reduction in UTIs occurrences in children managed for DES, DV or CFC [26, 28-30, $32,33,40]$.

American Academy of Pediatrics (AAP) published guidelines for the diagnosis and management of UTIs in febrile infants and young children younger than 2 years. No mention concerns evaluation and treatment of the associated constipation [46]. In the same way, the Italian Society of Pediatric Nephrology reports the recommendations for diagnosis and treatment of UTIs 
in children younger than 3 years, but did not mention evaluation and treatment of constipation in affected ones [47]. The American Urological Association (AUA) guidelines recommended a continuous antimicrobial prophylaxis as management of a child $>1$-year-old with VUR, recurrent febrile UTIs, bladder and bowel dysfunction, or renal cortical anomalies. No mention regards the constipation in affected children [48]. The European Urological Association reported that if symptomsm are suggestive of LUTD (urgency, incontinence, constipation, or holding manoeuvres), should do an extensive history and examination. No mention regarded constipation management in these children [49].

Only NICE clinical guideline (https://www.nice.org.uk/guidance/qs36) reported that constipation and DV are risk factors for UTIs and should as part of history and examination on confirmed UTI. A systematic review of 27 studies (1 RCT and 26 case studies) on the role of biofeedback in DES in paediatric patients showed a rate of improvement from $18 \%$ to $100 \%$ for constipation and of $83 \%$ in cases of UTI [50]. In children with severe constipation, a structured bowel management program decreases unplanned visits to the emergency department, hospital admissions, and costs for constipation-related health care for constipationrelated morbidities (abdominal pain 39\%, fecal impaction $17 \%$, urinary retention $2.2 \%$, urinary tract infections 14\%) [51].

\section{Limitations}

Further studies are necessary to show the effectiveness of constipation treatment regimens in preventing recurrent UTIs in children. In fact, most clinical trials, investigating the results of one or more treatments for constipation in the term of the resolution or amelioration of UTI recurrence, lacking in randomization and controlled groups. The published study results often involved small cohorts of patients or were only partial.

\section{CONCLUSION}

In conclusion, constipation seems to be a predisposing factor for UTIs recurrence in children. Studies were not homogenous but showed an improvement in UTIs occurrences in children managed for CFC or DES. Children referred to a paediatric nephrologist for UTIs should include an inquiry on bowel habits and those with a positive assessment for bowel dysfunction should by a paediatric gastroenterologist as a multidisciplinary approach.

\section{Abbreviations}

$\mathrm{CFC}=$ chronic functional constipation

$\mathrm{DES}=$ dysfunctional elimination syndromes

$\mathrm{DV}=$ dysfunctional voiding

LUTD $=$ lower urinary tract dysfunctions

$\mathrm{UTI}=$ urinary tract infection

VUR $=$ vesicoureteral reflux

\section{Conflict of interest}

The authors disclosed no conflict of interest during the preparation or publication of this manuscript.

\section{Financing}

The authors disclosed that they did not receive any grant during conduction or writing of this study.

\section{REFERENCES}

[1] White B. Diagnosis and treatment of urinary tract infections in children Am Fam Physician 2011;83:409-15.

[2] Vachvanichsanong P. Urinary tract infection: one lingering effect of childhood kidney diseases--review of the literature. J Nephrol 2007;20:21-8.

[3] Saadeh SA, Mattoo TK. Managing urinary tract infections. Pediatr Nephrol 2011;26:1967-76.

[4] Keren R, Shaikh N, Pohl H, Gravens-Mueller L, Ivanova A, Zaoutis L, et al. Risk factors for recurrent urinary tract infection and renal scarring. Pediatrics 2015;136:e13-21.

[5] Zaffanello M, Tardivo S, Cataldi L, Fanos V, Biban P, Malerba G. Genetic susceptibility to renal scar formation after urinary tract infection: a systematic review and meta-analysis of candidate gene polymorphisms. Pediatr Nephrol 2011;26:101729.

[6] Shaikh N, Hoberman A, Keren R, Gotman N, Docimo SG, Mathews $\mathrm{R}$, et al. Recurrent urinary tract infections in children with bladder and bowel dysfunction. Pediatrics 2016;137:e20152982.

[7] Dehghani SM, Basiratnia M, Matin M, Hamidpour L, Haghighat M, Imanieh MH. Urinary tract infection and enuresis in children with chronic functional constipation. Iran J Kidney Dis 2013;7:363-6.

[8] van den Berg MM, Benninga MA, Di Lorenzo C. 
Epidemiology of childhood constipation: a systematic review. Am J Gastroenterol 2006;101:2401-9.

[9] Benninga M, Candy DC, Catto-Smith AG, Clayden G, Loening-Baucke V, Di Lorenzo C et al. The Paris Consensus on Childhood Constipation Terminology (PACCT) Group. J Pediatr Gastroenterol Nutr 2005;40:273-5.

[10] Constipation Guideline Committee of the North American Society for Pediatric Gastroenterology, Hepatology and Nutrition. Evaluation and treatment of constipation in infants and children: recommendations of the North American Society for Pediatric Gastroenterology, Hepatology and Nutrition. J Pediatr Gastroenterol Nutr 2006;43:e1-13.

[11] Tabbers MM, DiLorenzo C, Berger MY, Faure C, Langendam MW, Nurko S, et al.; European Society for Pediatric Gastroenterology, Hepatology, and Nutrition; North American Society for Pediatric Gastroenterology. Evaluation and treatment of functional constipation in infants and children: evidence-based recommendations from ESPGHAN and NASPGHAN. J Pediatr Gastroenterol Nutr 2014;58:258-74.

[12] Xin HW, Fang XC, Zhu LM, Xu T, Fei GJ, Wang ZF, et al. Diagnosis of functional constipation: agreement between Rome III and Rome II criteria and evaluation for the practicality. J Dig Dis 2014;15:314-20.

[13] Halachmi S, Farhat WA. Interactions of constipation, dysfunctional elimination syndrome, and vesicoureteral reflux. Adv Urol 2008:828275.

[14] Austin PF, Bauer SB, Bower W, Chase J, Franco I, Hoebeke $\mathrm{P}$, et al. The standardization of terminology of lower urinary tract function in children and adolescents: Update report from the standardization committee of the International Children's Continence Society. Neurourol Urodyn 2016;35:471-81.

[15] Koff SA, Wagner TT, Jayanthi VR. The relationship among dysfunctional elimination syndromes, primary vesicoureteral reflux and urinary tract infections in children. J Urol 1998;160(3 Pt 2):1019-22.

[16] Sinha S. Dysfunctional voiding: A review of the terminology, presentation, evaluation and management in children and adults. Indian J Urol 2011;27:437-47.

[17] Kasirga E, Akil I, Yilmaz O, Polat M, Gozmen S, Egemen A. Evaluation of voiding dysfunctions in children with chronic functional constipation. Turk J Pediatr 2006;48:340-3.

[18] da Fonseca EM, Santana PG, Gomes FA, Bastos MD. Dysfunction elimination syndrome: is age at toilet training a determinant? J Pediatr Urol 2011;7:332-5.

[19] Romanczuk W, Korczawski R. Chronic constipation: a cause of recurrent urinary tract infections. Turk J Pediatr 1993;35:1818.

[20] Giramonti KM, Kogan BA, Agboola OO, Ribons L, Dangman B. The association of constipation with childhood urinary tract infections. J Pediatr Urol 2005;1:273-8.

[21] Wan J, Kaplinsky R, Greenfield S. Toilet habits of children evaluated for urinary tract infection. J Urol 1995;154(2 Pt 2):7979.

[22] Blethyn AJ, Jenkins HR, Roberts R, Verrier Jones K. Radiological evidence of constipation in urinary tract infection. Arch Dis Child 1995;73:534-5.

[23] Chrzan R, Klijn AJ, Vijverberg MA, Sikkel F, de Jong TP.
Colonic washout enemas for persistent constipation in children with recurrent urinary tract infections based on dysfunctional voiding. Urology 2008;71:607-10.

[24] Ojetti V, Bruno G, Paolucci V, Triarico S, D'aversa F, Ausili $\mathrm{E}$, et al. The prevalence of small intestinal bacterial overgrowth and methane production in patients with myelomeningocele and constipation. Spinal Cord 2014;52:61-4.

[25] Kibar Y, Ors O, Demir E, Kalman S, Sakallioglu O, Dayanc M. Results of biofeedback treatment on reflux resolution rates in children with dysfunctional voiding and vesicoureteral reflux. Urology 2007;70:563-6; discussion 6-7.

[26] Vesna Z, Milica L, Marina V, Andjelka S, Lidija D. Correlation between uroflowmetry parameters and treatment outcome in children with dysfunctional voiding. J Pediatr Urol 2010;6:396-402.

[27] Vesna ZD, Milica L, Stankovic I, Marina V, Andjelka S. The evaluation of combined standard urotherapy, abdominal and pelvic floor retraining in children with dysfunctional voiding. J Pediatr Urol 2011;7:336-41.

[28] Zivkovic V, Lazovic M, Vlajkovic M, Slavkovic A, Dimitrijevic L, Stankovic I, et al. Diaphragmatic breathing exercises and pelvic floor retraining in children with dysfunctional voiding. Eur J Phys Rehabil Med 2012;48:413-21. [29] Kajbafzadeh AM, Sharifi-Rad L, Ghahestani SM, Ahmadi H, Kajbafzadeh M, Mahboubi AH. Animated biofeedback: an ideal treatment for children with dysfunctional elimination syndrome. J Urol 2011;186:2379-84.

[30] Humphreys MR, Vandersteen DR, Slezak JM, Hollatz P, Smith CA, Smith JE, et al. Preliminary results of sacral neuromodulation in 23 children. J Urol 2006; 176:2227-31.

[31] De Paepe H, Renson C, Van Laecke E, Raes A, Vande Walle J, Hoebeke P. Pelvic-floor therapy and toilet training in young children with dysfunctional voiding and obstipation. BJU Int 2000;85:889-93.

[32] Vasconcelos M, Lima E, Caiafa L, Noronha A, Cangussu R, Gomes S, et al. Voiding dysfunction in children. Pelvic-floor exercises or biofeedback therapy: a randomized study. Pediatr Nephrol 2006;21:1858-64.

[33] Yagci S, Kibar Y, Akay O, Kilic S, Erdemir F, Gok F, et al. The effect of biofeedback treatment on voiding and urodynamic parameters in children with voiding dysfunction. J Urol 2005;174:1994-7; discussion 7-8.

[34] McKenna PH, Herndon CD, Connery S, Ferrer FA. Pelvic floor muscle retraining for pediatric voiding dysfunction using interactive computer games. J Urol 1999;162(3 Pt 2):1056-62; discussion 62-3.

[35] Barroso U Jr, Lordelo P, Lopes AA, Andrade J, Macedo A $\mathrm{Jr}$, Ortiz V. Nonpharmacological treatment of lower urinary tract dysfunction using biofeedback and transcutaneous electrical stimulation: a pilot study. BJU Int 2006;98:166-71.

[36] Petronijevic V, Lazovic M, Vlajkovic M, Slavkovic A, Golubovic E, Miljkovic P. Botulinum toxin type A in combination with standard urotherapy for children with dysfunctional voiding. J Urol 2007;178:2599-602; discussion 602-3.

[37] O'Regan S, Yazbeck S, Schick E. Constipation, bladder instability, urinary tract infection syndrome. Clin Nephrol 1985;23:152-4. 
[38] Loening-Baucke V. Urinary incontinence and urinary tract infection and their resolution with treatment of chronic constipation of childhood. Pediatrics 1997;100(2 Pt 1):228-32.

[39] Loening-Baucke V. Factors determining outcome in children with chronic constipation and faecal soiling. Gut 1989;30:9991006.

[40] Tugtepe H, Thomas DT, Ergun R, Abdullayev T, Kastarli C, Kaynak A, et al. Comparison of biofeedback therapy in children with treatment-refractory dysfunctional voiding and overactive bladder. Urology 2015;85:900-4.

[41] Khen-Dunlop N, Van Egroo A, Bouteiller C, Biserte J, Besson R. Biofeedback therapy in the treatment of bladder overactivity, vesico-ureteral reflux and urinary tract infection. J Pediatr Urol 2006;2:424-9.

[42] Amira PA, Dusan P, Gordana ML, Sandra T, Ivanisevic I. Bladder control training in girls with lower urinary tract dysfunction. Int Braz J Urol 2013;39:118-26.

[43] Sarvari G, Sharbaf FG, Partovi S, Elmi S, Akhavan H, Bakhtiari E. The relationship between chronic constipation and urinary tract infection in children: A case-control clinical study. Int J Pediatr 2017;5:5715-21.

[44] Montini G, Tullus K, Hewitt I. Febrile urinary tract infections in children. N Engl J Med 2011;365:239-50.

[45] Morello W, La Scola C, Alberici I, Montini G. Acute pyelonephritis in children. Pediatr Nephrol 2016;31:1253-65.
[46] Roberts KB. Urinary tract infection: clinical practice guideline for the diagnosis and management of the initial UTI in febrile infants and children 2 to 24 months. Pediatrics 2011;128:595-610.

[47] Ammenti A, Cataldi L, Chimenz R, Fanos V, La Manna A, Marra G, et al. Febrile urinary tract infections in young children: recommendations for the diagnosis, treatment and follow-up. Acta Paediatr 2012;101:451-7.

[48] Peters CA, Skoog SJ, Arant BS Jr, Copp HL, Elder JS, Hudson RG, et al. Summary of the AUA Guideline on Management of Primary Vesicoureteral Reflux in Children. J Urol 2010;184:1134-44.

[49] Tekgül S, Riedmiller H, Hoebeke P, Kočvara R, Nijman RJ, Radmayr C, et al. EAU guidelines on vesicoureteral reflux in children. Eur Urol 2012;62:534-42.

[50] Desantis DJ, Leonard MP, Preston MA, Barrowman NJ, Guerra LA. Effectiveness of biofeedback for dysfunctional elimination syndrome in pediatrics: a systematic review. J Pediatr Urol 2011;7:342-8.

[51] Reck-Burneo CA, Vilanova-Sanchez A, Gasior AC, Dingemans AJM, Lane VA, Dyckes R, et al. A structured bowel management program for patients with severe functional constipation can help decrease emergency department visits, hospital admissions, and healthcare costs. J Pediatr Surg 2018;53:1737-41. 